Article

\title{
Design and Validation of a Questionnaire to Measure Future Spanish Teachers' Perceptions of Cinema in Pre-School and Primary Education: Towards Active and Technological Learning
}

\author{
Alejandro Lorenzo-Lledó \\ Department of Development Psychology and Teaching, Faculty of Education, University of Alicante, \\ 03690 San Vicente del Raspeig, Spain; alejandro.lorenzo@ua.es
}

Received: 17 August 2020; Accepted: 31 August 2020; Published: 3 September 2020

\begin{abstract}
State of the art: Cinema, because of the eclectic nature of art, technology and mass media, can be manifested as an educational tool in the classroom. In this sense, the educational possibilities detected in the cinema are numerous. The pre-service teacher education in the figure of the teacher determines their educational resources. Purpose: The general objective of this study is to design and validate an instrument to measure the perceptions of students of Pre-School Teacher Degree and Primary Teacher Degree in Spanish universities about cinema as a teaching resource in Pre-School and Primary Education. Design/methodology: For this purpose, a systematic and planned process was developed for the design and validation of the Percepciones sobre las potencialidades del cine como recurso didáctico en las aulas de Infantil y Primaria ((PECID) (perceptions about the potentialities of cinema as a didactic resource in pre-school and primary classrooms)) questionnaire. Main findings: The results obtained showed a good content validity of 25 items after an expert judgement. On the other hand, a reliability of the internal consistency of the instrument of 0.978 was obtained. Furthermore, a three-factor structure was confirmed through factor analysis. Conclusions: It is concluded that the PECID questionnaire is a valid and reliable instrument to measure the perceptions of future teachers in Spain about using cinema as a resource for future teaching.
\end{abstract}

Keywords: cinema; audio-visual; future teachers; active learning; technological learning; multimedia; psychometric study; instrument validation; educational enhancement

\section{Introduction}

Current society is decisively marked by the digital media and the culture of the image, which has an influence on many areas, including education, making new demands in training. In this sense, [1] suggested the need to revise the notion of literacy in view of the supremacy of the visual and of multimodal communication practices, such as audio-visual language.

Among the audio-visual media is cinema, understood as moving pictures. Due to the eclectic nature of art, technology and mass media, cinema can manifest itself as an educational tool in the classroom in various ways, depending on the role it is given. At the didactic level, [2] distinguished between educating with the cinema and educating in the cinema, in other words, as a teaching aid or as a creative process and to teach how to look at it with more critical eyes, creating responsible spectators. Furthermore, [3] distinguished, on the one hand, cinema as an educational resource (cinema in education) in which cinema would be inserted as a support in subjects and the study of cinema as an art. On the other hand, there would be the media (education in cinema), which would include the critical dimension and the creative dimension. 
Nevertheless, it should be stressed that cinema should be understood as more than just a teaching aid. It can therefore be a tool that empowers and is an ally in both teaching and learning [4]. Along these lines, this study advocates an integrated and integral vision of cinema in education, contemplating all its possibilities. More specifically, cinema is understood as a didactic resource (support and assistance) in learning strategies and as a means of audio-visual communication integrated into a society. Education is needed for the knowledge and use of the media (functions, language, expression) and the critical vision of them, promoting an autonomous and active development of the students.

From the scientific literature, numerous educational possibilities of the cinema have been detected. In this sense, the cinema has been described as a powerful transmitter of content of all kinds, especially to work on values and attitudes that promote peaceful coexistence and intercultural sensitivity $[5,6]$, in addition to promoting behaviors that help others [7]. T. Kubrak confirmed the positive impact that cinema can have on attitudes towards current social issues [8]. In addition, its ability to capture the attention of and motivate students, generating active, suggestive and experiential learning has been highlighted $[9,10]$. The cinema is appropriate for students to better understand the concepts worked on [11]. On the other hand, the suitability of cinema to develop creativity has been confirmed, being an open door to imagination and divergent thinking [12]. Along these lines, [13] added the capacity of cinema, as a compendium of all the arts, to stimulate expressive and communicative skills. Ref. [14] proposed films with subtitles as an ideal means of learning languages. Moreover, cinema has been pointed out as suitable for encouraging reflection, research [15,16] and debate [17,18]. Likewise, Ref. [19] approached cinema as a tool to develop students' critical sense towards audio-visual works, knowledge of their language and the process of creation. $[20,21]$ exposed the usefulness of cinema to learn how to master the technological tools for creating multimedia works and generate reflection at the same time. Moreover, cinema has an interdisciplinary scope that makes holistic learning possible [22,23]. In this line, [24] deepened the existing links between cinema and literature, which can be used in the educational field for transversal learning.

If one considers the Spanish educational regulations, it is important to note that Ley Orgánica para la mejora de la calidad educativa ((LOMCE) (Foundational Law for the Improvement of Educational Quality in Spain)) indicates as one of the objectives for Primary Education "to use different artistic representations and expressions and to begin to construct visual and audiovisual proposals" [25]. For its part, Real Decreto 1630/2006, of 29 December, for the second cycle of Pre-school Education, in the area of Languages: Communication and Representation, includes as curricular content "initiation to the use of technological instruments such as the camera", "approaching audiovisual productions such as films" and "critical evaluation of their content and aesthetics" [26].

Moreover, Real Decreto 126/2014, of 28 February, establishes for Primary Education, in block 5 of Natural Sciences, as a learning standard "knows and explains some of the advances of science in cinema" [27]. On the other hand, in the subject of Plastic Education, it is also established as a learning standard "it recognizes the animation cinema as a genre of cinema and it comments the process used for the creation, editing and diffusion of an animation film" [27]. In the regional scope, F. Lara et al. have analyzed the presence of cinema in the regional curricula of Pre-School and Primary Education, confirming that it is present, although in an unequal way [3]. In this sense, in Primary Education, cinema as an educational support resource is contemplated in all Autonomous Communities, but only in Madrid and in Andalusia is it also present as a critical analysis of the audio-visual, as a form of own film production and as an art form.

In this context, the university, as the last educational step, is indispensable, as [28] indicated, to be synchronized with school and society. This is even more necessary if we take into account that for the figure of the teacher, the pre-service teacher education is a key period that marks their future teaching practice, emerging as one of the critical points of the educational system [29]. In view of the educational value of film and its inclusion in the curriculum of pre-school and primary education, we should ask ourselves how future teachers in Spain perceive this educational resource in all its dimensions, since, as [30] indicated, the perception of the usefulness of a resource is an essential requirement for its future 
involvement in teaching practice. In this sense, in the absence of instruments to do so, this paper sets out as a general objective to design and validate an instrument to measure the perceptions of students in the Teacher's Degree in Spanish universities about film as a teaching resource in Pre-School and Primary Education. From the aforementioned general objective, the following specific objectives underlie:

1. To evaluate the validity of the content of the instrument;

2. To analyze the reliability of the internal consistency of the instrument;

3. To examine the construct validity of the instrument's factor structure.

\section{Materials and Methods}

For the construction of the instrument, a systematic and planned process was followed in which, according to [31], the definition of variables, the construction and organization of the items, the pilot study, the estimation of reliability and the obtaining of evidence of validity must be considered.

\subsection{Participants}

Being a study for the validation of an instrument at the national level, the participating sample was composed of 4659 students of the Teacher's Degrees, belonging to all the Autonomous Communities and 58 universities, 39 public and 19 private. A technique of quota sampling was used to conform the sample [32]. As many as $15.5 \%(n=720)$ of the participants were men and $84.5 \%(n=3939)$ were women, with a mean age of 22.3 years $(\mathrm{SD}=3.9)$. In turn, $49.0 \%(n=2281)$ were students in the Pre-School Education Training Degree and 51.0\% $(n=2378)$ in the Primary Education Training Degree. Moreover, $89.8 \%(n=4183)$ were students from public universities and $10.2 \%(n=476)$ were from private universities. In relation to the territorial distribution, the following Table 1 shows the frequencies and percentages of the participating students according to the Autonomous Community.

Table 1. Participant sample according to the university [33].

\begin{tabular}{ccc}
\hline \multirow{2}{*}{ Autonomous Community } & \multicolumn{2}{c}{ Students } \\
\cline { 2 - 3 } & $\boldsymbol{N}$ & $\%$ \\
\hline Andalusia & 1161 & 24.9 \\
Aragon & 69 & 1.5 \\
Asturias & 99 & 2.1 \\
Balearic Islands & 76 & 1.6 \\
Canary Islands & 205 & 4.4 \\
Cantabria & 45 & 1.0 \\
Castilla-La Mancha & 110 & 2.4 \\
Castile and Leon & 171 & 3.7 \\
Catalonia & 642 & 13.8 \\
Valencian Community & 601 & 12.9 \\
Extremadura & 88 & 1.9 \\
Galicia & 251 & 5.4 \\
Madrid & 636 & 13.7 \\
Murcia & 218 & 4.7 \\
Navarre & 71 & 1.5 \\
Basque Country & 156 & 3.3 \\
La Rioja & 60 & 1.3 \\
\hline Total & 4659 & 100.0
\end{tabular}

On the other hand, regarding the participating students according to the university they belong to, Table 2 is presented. 
Table 2. Participant sample according to the university [33].

\begin{tabular}{|c|c|c|}
\hline University & $N$ & $\%$ \\
\hline University of A Coruña & 119 & 2.6 \\
\hline University of Alcalá & 166 & 3.6 \\
\hline Alfonso X El Sabio University & 3 & 0.1 \\
\hline University of Alicante & 196 & 4.2 \\
\hline University of Almería & 23 & 0.5 \\
\hline Nebrija University & 19 & 0.4 \\
\hline Autonomous University of Barcelona & 73 & 1.6 \\
\hline Autonomous University of Madrid & 154 & 3.3 \\
\hline University of Barcelona & 64 & 1.4 \\
\hline University of Burgos & 24 & 0.5 \\
\hline University of Cádiz & 155 & 3.3 \\
\hline Camilo José Cela University & 24 & 0.5 \\
\hline University of Cantabria & 41 & 0.9 \\
\hline CEU Cardenal Herrera University & 35 & 0.8 \\
\hline University of Castilla La Mancha & 110 & 2.4 \\
\hline Catholic University San Antonio & 33 & 0.7 \\
\hline Catholic University Santa Teresa de Jesús de Ávila & 2 & 0.0 \\
\hline Valencia Catholic University San Vicente Mártir & 9 & 0.2 \\
\hline Complutense University of Madrid & 45 & 1.0 \\
\hline University of Córdoba & 224 & 4.8 \\
\hline University of Deusto & 13 & 0.3 \\
\hline European University of the Atlantic & 4 & 0.1 \\
\hline University of Extremadura & 88 & 1.9 \\
\hline Francisco de Vitoria University & 13 & 0.3 \\
\hline University of Girona & 158 & 3.4 \\
\hline University of Granada & 116 & 2.5 \\
\hline University of Huelva & 101 & 2.2 \\
\hline University of the Islas Baleares & 76 & 1.6 \\
\hline International University of Cataluña & 8 & 0.2 \\
\hline Jaume I University & 223 & 4.8 \\
\hline University of Jaén & 25 & 0.5 \\
\hline University of La Laguna & 88 & 1.9 \\
\hline University of La Rioja & 60 & 1.3 \\
\hline University of Las Palmas de Gran Canaria & 117 & 2.5 \\
\hline University of León & 27 & 0.6 \\
\hline University of Lleida & 111 & 2.4 \\
\hline Loyola University Andalucía & 30 & 0.6 \\
\hline Mondragón University & 70 & 1.5 \\
\hline University of Murcia & 185 & 4.0 \\
\hline University of Málaga & 186 & 4.0 \\
\hline University of Navarra & 23 & 0.5 \\
\hline University of Oviedo & 99 & 2.1 \\
\hline University of País Vasco & 73 & 1.6 \\
\hline Comillas Pontifical University & 32 & 0.7 \\
\hline Pontifical University of Salamanca & 33 & 0.7 \\
\hline Public University of Navarra & 48 & 1.0 \\
\hline Ramon Llull University & 96 & 2.1 \\
\hline Rey Juan Carlos University & 180 & 3.9 \\
\hline Rovira i Virgili University & 118 & 2.5 \\
\hline University of Salamanca & 54 & 1.2 \\
\hline San Jorge University & 15 & 0.3 \\
\hline University of Santiago de Compostela & 35 & 0.8 \\
\hline University of Sevilla & 301 & 6.5 \\
\hline University of Valladolid & 31 & 0.7 \\
\hline University of Valencia & 138 & 3.0 \\
\hline University of Vic & 14 & 0.3 \\
\hline University of Vigo & 97 & 2.1 \\
\hline University of Zaragoza & 54 & 1.2 \\
\hline Total & 4659 & 100.0 \\
\hline
\end{tabular}


To determine the representativeness of the sample, the following formula was used $n=\mathrm{K}^{2} \mathrm{p} \mathrm{q} \mathrm{N} / \mathrm{E}^{2}$ $(\mathrm{N}-1)+\mathrm{K}^{2} \mathrm{p} \mathrm{q}$, which is suitable for the application to finite populations. According to the Spanish Ministry of Education, the student population of the Teacher's Degree in Spain is 118,525. Considering this, the total sample is representative of the chosen population with a sampling error of $1.4 \%$ and a confidence level of $95.5 \%$.

\subsection{Variables}

The definition of the measurement variable, according to [34], is a previous step for the optimal construction of the items of an instrument. [35] stated that in order to constitutively define a variable, words or concepts that theoretically describe the construct can be used. In the present research, the variable of interest was the perceptions of the Teacher's Degree students about the potential of cinema as a didactic resource in Pre-School and Primary Education, which was defined as the perceptions about the didactic possibilities offered by cinema to develop the teaching-learning processes in the Pre-School and Primary Education stages. This variable was broken down into three dimensions:

1. The potential of cinema as a didactic resource of the transmission of content. It is conceptualized as the mediating possibilities of cinema as a support for communication and symbolic representation to transmit concepts, attitudes and values to students;

2. The potential of cinema as a didactic resource of expression and communication. It is conceptualized as the mediating possibility of cinema as a form of representation and projection to develop relationships and exchange of information among students;

3. The potentialities of cinema as a didactic resource of critical analysis. It is conceptualized as the mediating possibility of cinema to develop in students a conscious and proper analysis of reality.

\subsection{Procedure}

The data collection had several phases. First of all, we proceeded to identify the Spanish universities, both public and private, in the different territories, which offered the Teacher's Degree, based on the data provided by the Spanish Ministry of Education. As a result, it was determined that in Spain, 63 universities offer the Teacher's Degree, 39 public and 24 private. Secondly, the teaching staff of these universities were contacted by e-mail to inform them of the objectives of the research and to request their collaboration in disseminating the questionnaire among the students. Of all the universities, five private universities refused to participate in the study. Finally, data were obtained by filling out the questionnaire in Spanish by the students during the 2018/2019 academic year through Google Forms. Students were informed that their participation in the research was voluntary and anonymous. In this sense, any personal data that identified the students and that did not respect the confidentiality of the data were excluded from the questionnaire.

\subsection{Data Analysis}

To analyze the content validity and reliability of the internal consistency of the instrument, the statistical package SPSS for Windows in its version 21 (IBM Corp., Armonk, NY, USA) was used. For factorial analysis, the program SPSS was used in the exploratory analysis and the program Mplus in its version 8 [36] in the confirmatory analysis. For these analyses, the total sample was randomly divided into two different samples, as recommended by [37], one from 2330 participants for exploratory factor analysis and the other from 2329 participants for confirmatory factor analysis. In the exploratory factor analysis, the principal component analysis was chosen as the extraction method and Varimax was chosen as the rotation method. Likewise, in the confirmatory factor analysis, the estimation method used was the diagonally weighted least squares method (WLSMV). In relation to the values of asymmetry and kurtosis, these are less than 2 and 7, respectively, so following [37,38], they are considered within normality. 


\section{Results}

The following are the results of this study, which were grouped according to the validation and reliability phases of the instrument.

\subsection{Content Validy}

Based on the review of the literature on cinema in education and Spanish educational regulations, a first version of the questionnaire was developed. It is worth noting that, as there were no previous questionnaires measuring the variables chosen, we opted to design the questionnaire ad hoc, which was assigned the name Percepciones sobre las potencialidades del cine como recurso didáctico en las aulas de Infantil y Primaria ((PECID) (perceptions about the potentialities of cinema as a didactic resource in pre-school and primary classrooms)). A Likert-type scale of 28 items was designed to measure the perceptions of the Teacher's Degree students about the potential of cinema in Pre-School and Primary Education, based on the theoretical definition of the variable and the dimensions considered in it. In this sense, the items of the scale were organized according to the dimensions, integrating the first dimension items 1 to 10 , the second dimension items 11 to 19 , and the third dimension items 20 to 28 . Six response categories were established, from the minimum favorable attitude $(1=$ totally disagree $)$ to the maximum ( 6 = totally agree), passing through different intermediate degrees of agreement/disagreement ( 2 = quite disagree; 3 = something disagree; 4 = something agree; 5 = quite agree). Considering that the elimination of the intermediate alternative in a scale can contribute to preventing biases of central tendency and social desirability [39-43], it was -chosen not to include the option of indifference, but a balanced and symmetrical scale was designed with the same number of degrees of agreement as of disagreement. Prior to the scale of perceptions, three sections were included dedicated to demographic data, film consumption habits and training in the didactic use of cinema. On the other hand, a last item was included as a conclusion of the questionnaire about the predisposition to use cinema in the future teaching exercise.

The first step to estimate the validity of the items constructed to measure perceptions about cinema in Pre-School and Primary Education was to evaluate their content validity, which, according to [44], implies the analysis of the content of an instrument to determine if the items that compose it are a relevant and representative sample of the construct to be measured. In order to obtain the validity of the content, numerous authors, such as [45-47], have pointed to the judgment of experts as the most appropriate mechanism. Thus, [45] specified that with the judgment of experts, the informed opinion of people with a background in a subject can be obtained, who are recognized by others as qualified experts in the same field. To specify the degree of agreement among the experts, [48] stressed that it is essential that they can provide a quantitative assessment of the items. Among the various existing empirical methods to quantify the degrees of agreement, the one proposed by [49] was chosen, based on the content validity coefficient (CVC). This coefficient makes it possible to assess the degree of agreement among experts with respect to each of the items and to the instrument in general. In this sense, to reduce the possible bias introduced by some of the judges, an error assigned to each item $\left(\mathrm{Pe}_{\mathrm{i}}\right)$ was proposed, which was calculated with the formula $P e_{i}=(1 / j)^{j}$, where $j$ is the number of experts. Therefore, the final value of the $\mathrm{CVC}$ is the result of applying this error to the $\mathrm{CVC}_{\mathrm{i}}$ of each item, that is, $\mathrm{CVC}=\mathrm{CVC}_{\mathrm{i}}-\mathrm{Pe}_{\mathrm{i}}$.

To determine the status of the expert, it was taken into account, on the one hand, that they were a teacher with more than fifteen years of experience, either at a university with a profile in education or in audio-visual communication or at a non-university educational center. On the other hand, it was defined that they had a recognized research profile in the field of cinema in education. Ten experts from various Autonomous Communities agreed to participate in the evaluation, six of whom were senior lecturers, one was a full professor, one was a lecturer and two were from non-university educational centers. In order for the experts to examine the content of the instrument, following the recommendation of [45], a template was drawn up, which first included a letter of presentation, with express mention of the research objectives. Secondly, it described the structure of the questionnaire 
and the variables to be measured. Thirdly, the relevant instructions for evaluating the questionnaire and the description of the criteria for assessing each item, i.e., relevance, were detailed, establishing a scale of five alternatives for quantifying it ( $1=$ very little relevance, $2=$ little relevance, $3=$ moderately relevant, $4=$ quite relevant and $5=$ very much relevant). After the instructions, the questionnaire to be evaluated was included. In each item, a box was also added where the judge could make observations on the understanding of the items, or any other comment that they considered appropriate. Likewise, at the end of the questionnaire, a box was added where the judges could make global observations of the questionnaire as a general evaluation.

The scores given by the experts are presented in Table 3. In order to assess the scores, it is worth bearing in mind what [49] said, recommending only keeping those items with a CVC higher than 0.80 .

Table 3. Scores of the experts on the items of the Percepciones sobre las potencialidades del cine como recurso didáctico en las aulas de Infantil y Primaria ((PECID) (perceptions about the potentialities of cinema as a didactic resource in pre-school and primary classrooms)) questionnaire.

\begin{tabular}{ccccccccccccccc}
\hline Items & & & & & & \multicolumn{1}{c}{ Experts } & & & & & & \\
\hline & $\mathbf{1}$ & $\mathbf{2}$ & $\mathbf{3}$ & $\mathbf{4}$ & $\mathbf{5}$ & $\mathbf{6}$ & $\mathbf{7}$ & $\mathbf{8}$ & $\mathbf{9}$ & $\mathbf{1 0}$ & $\mathbf{M}_{\mathbf{x}}$ & $\mathbf{V}_{\mathbf{m a x}}$ & $\mathbf{C V C}_{\mathbf{i}}$ & $\mathbf{C V C}$ \\
\hline 1 & 3 & 5 & 5 & 2 & 3 & 5 & 5 & 5 & 3 & 5 & 4.10 & 5.00 & 0.82 & 0.82 \\
2 & 5 & 5 & 5 & 5 & 3 & 5 & 5 & 5 & 3 & 3 & 4.40 & 5.00 & 0.88 & 0.88 \\
3 & 5 & 2 & 5 & 3 & 2 & 5 & 5 & 5 & 3 & 5 & 4.10 & 5.00 & 0.82 & 0.82 \\
4 & 5 & 5 & 5 & 5 & 2 & 5 & 5 & 2 & 5 & 5 & 4.40 & 5.00 & 0.88 & 0.88 \\
5 & 5 & 5 & 3 & 3 & 3 & 3 & 3 & 2 & 5 & 5 & 3.70 & 5.00 & 0.74 & 0.74 \\
6 & 5 & 3 & 5 & 5 & 5 & 5 & 5 & 5 & 5 & 5 & 4.80 & 5.00 & 0.96 & 0.96 \\
7 & 5 & 3 & 5 & 5 & 5 & 5 & 5 & 5 & 5 & 5 & 4.80 & 5.00 & 0.96 & 0.96 \\
8 & 5 & 3 & 5 & 5 & 5 & 3 & 5 & 5 & 3 & 5 & 4.40 & 5.00 & 0.88 & 0.88 \\
9 & 5 & 5 & 5 & 5 & 5 & 5 & 5 & 5 & 5 & 5 & 5.00 & 5.00 & 1.00 & 1.00 \\
10 & 5 & 5 & 5 & 5 & 5 & 5 & 5 & 5 & 5 & 5 & 5.00 & 5.00 & 1.00 & 1.00 \\
11 & 5 & 3 & 5 & 2 & 5 & 3 & 5 & 5 & 3 & 5 & 4.10 & 5.00 & 0.82 & 0.82 \\
12 & 5 & 3 & 5 & 5 & 5 & 5 & 5 & 5 & 3 & 5 & 4.60 & 5.00 & 0.92 & 0.92 \\
13 & 3 & 5 & 5 & 5 & 5 & 5 & 5 & 5 & 4 & 4 & 4.60 & 5.00 & 0.92 & 0.92 \\
14 & 2 & 4 & 5 & 5 & 5 & 5 & 5 & 5 & 4 & 5 & 4.50 & 5.00 & 0.90 & 0.90 \\
15 & 3 & 3 & 5 & 5 & 5 & 5 & 5 & 5 & 5 & 5 & 4.60 & 5.00 & 0.92 & 0.92 \\
16 & 3 & 3 & 5 & 5 & 5 & 5 & 5 & 4 & 5 & 5 & 4.50 & 5.00 & 0.90 & 0.90 \\
17 & 3 & 3 & 5 & 5 & 5 & 5 & 5 & 5 & 5 & 5 & 4.60 & 5.00 & 0.92 & 0.92 \\
18 & 3 & 3 & 5 & 5 & 5 & 5 & 5 & 5 & 3 & 3 & 3.70 & 5.00 & 0.74 & 0.74 \\
19 & 5 & 5 & 5 & 5 & 5 & 5 & 5 & 5 & 3 & 3 & 4.60 & 5.00 & 0.92 & 0.92 \\
20 & 3 & 4 & 5 & 5 & 5 & 5 & 5 & 5 & 3 & 5 & 4.50 & 5.00 & 0.90 & 0.90 \\
21 & 2 & 5 & 5 & 5 & 5 & 5 & 5 & 5 & 5 & 5 & 4.70 & 5.00 & 0.94 & 0.94 \\
22 & 3 & 2 & 5 & 5 & 5 & 5 & 5 & 5 & 5 & 5 & 4.50 & 5.00 & 0.90 & 0.90 \\
23 & 4 & 5 & 5 & 5 & 5 & 5 & 5 & 5 & 5 & 4 & 4.80 & 5.00 & 0.96 & 0.96 \\
24 & 4 & 5 & 5 & 5 & 5 & 4 & 5 & 5 & 3 & 5 & 4.60 & 5.00 & 0.92 & 0.92 \\
25 & 2 & 2 & 5 & 5 & 5 & 5 & 5 & 5 & 3 & 3 & 4.10 & 5.00 & 0.82 & 0.82 \\
26 & 3 & 4 & 5 & 4 & 5 & 5 & 5 & 5 & 3 & 5 & 3.70 & 5.00 & 0.74 & 0.74 \\
27 & 2 & 5 & 5 & 5 & 5 & 5 & 5 & 5 & 3 & 5 & 4.50 & 5.00 & 0.90 & 0.90 \\
28 & 4 & 5 & 5 & 5 & 5 & 5 & 5 & 5 & 3 & 4 & 4.60 & 5.00 & 0.92 & 0.92 \\
\hline
\end{tabular}

Note 1: $\mathrm{M}_{\mathrm{x}}=$ mean of each item; $\mathrm{V}_{\max }=$ maximum value; $C V C_{\mathrm{i}}=$ content validity coefficient without error; final content validity coefficient $(\mathrm{CVC})=$ final content validity factor. Note 2: Error assigned to each item $\left(\mathrm{Pe}_{\mathrm{i}}\right)=10^{-10}$.

As it can be seen, items 5, 18 and 26 have a CVC of 0.74 , so they were eliminated, keeping the rest of the items. On the other hand, in the observations' section, some improvements proposed by the judges were taken into account, such as those aimed at making some items more precise. After carrying out this process, a valid content level instrument was obtained, consisting of 25 items, which represented the second version of the PECID questionnaire. 


\subsection{Pilot Test}

The pre-test using a reduced and similar sample of subjects, following [50], is a phase that contributes to reinforce the validity of a designed measurement instrument and therefore it was chosen to be conducted. In this line, [51] added that it is convenient to carry out a pilot test, because it contributes to identify incorrectness in the instrument, estimate the time needed to complete it, review the clarity of the items, as well as estimate the reliability.

After submitting the questionnaire to expert judgment, the version obtained was transferred to Google Forms and a pilot test was carried out with a sample of students during class hours. As this was a nationwide study covering the different Autonomous Communities, the pilot was carried out with 134 students chosen for convenience at two universities in different communities, specifically at the University of Alicante and the University of Barcelona. Of these, $14.9 \%(n=20)$ were men and $85.1 \%(n=114)$ were women, with a mean age of 21.1 years $(\mathrm{SD}=4.1)$. Likewise, $42.6 \%(n=57)$ of the students were in the Pre-School Education Teacher's Degree and 57.4\% $(n=77)$ in the Primary Education Teacher's Degree. After completing the questionnaire, the time needed to complete it was recorded and the participating students were asked to express their opinion about the design of the questionnaire, the writing, the understanding of the items and any other aspect they considered could be improved, and this was collected in writing.

Firstly, it was found that the time of completion of the questionnaire was reduced, BY approximately five minutes, and that there was no fatigue in the students. Secondly, the opinions collected were favorable to the questionnaire, although some aspects that could be improved were identified. In this sense, in items 17 and 25, examples were added to facilitate understanding. Furthermore, additional information was included for completion and a more visually attractive design was promoted by adding a header image and changing the colors. The improvements made resulted in the third version of the PECID questionnaire, ready to be passed on to the final sample.

\subsection{Reliability}

After carrying out this process, a valid content level instrument was obtained, consisting of 25 items, which represented the second version of the PECID questionnaire. To analyze the reliability of the internal consistency of the instrument, the Cronbach Alpha coefficient was calculated.

Before the application of the questionnaire to the final sample, and from the data obtained in the pilot test with 134 students, the Cronbach's Alpha coefficient of the 25 item scale of perceptions about the potential of cinema as a teaching resource in the Pre-School and Primary Education was preliminarily calculated. The analysis resulted in an Alpha of 0.970, which according to [52], is an excellent reliability value, since it reflects that the answers have a high degree of coherence around the same domain, that is, the perceptions of the potentialities of cinema in the pre-school and primary classrooms.

Once the questionnaire was applied to the total sample of 4659 students, which did not include the participants in the pilot test, the reliability of the scale was again analyzed. The result of the Cronbach's Alpha was again very high, specifically 0.978 , with an outstanding reliability value. In addition, in Table 4, the results relating to the item-total correlations and the Cronbach's Alpha coefficient are presented if each of the items is eliminated.

Table 4. Correlations and internal consistency indexes obtained in the final sample.

\begin{tabular}{cccc}
\hline Items & Corrected Item-Total Correlation & Multiple Squared Correlation & Cronbach's Alpha if the Item Is Removed \\
\hline 1 & 0.758 & 0.721 & 0.977 \\
2 & 0.748 & 0.711 & 0.977 \\
3 & 0.757 & 0.733 & 0.977 \\
4 & 0.764 & 0.726 & 0.977 \\
5 & 0.795 & 0.776 & 0.977 \\
6 & 0.781 & 0.754 & 0.977 \\
7 & 0.775 & 0.778 & 0.977 \\
8 & 0.807 & 0.834 & 0.977 \\
9 & 0.765 & 0.748 & 0.977 \\
\hline
\end{tabular}


Table 4. Cont.

\begin{tabular}{cccc}
\hline Items & Corrected Item-Total Correlation & Multiple Squared Correlation & Cronbach's Alpha if the Item Is Removed \\
\hline 10 & 0.808 & 0.774 & 0.977 \\
11 & 0.828 & 0.816 & 0.976 \\
12 & 0.815 & 0.768 & 0.976 \\
13 & 0.757 & 0.720 & 0.977 \\
14 & 0.827 & 0.828 & 0.976 \\
15 & 0.836 & 0.840 & 0.976 \\
16 & 0.844 & 0.832 & 0.976 \\
17 & 0.786 & 0.745 & 0.977 \\
18 & 0.786 & 0.782 & 0.977 \\
19 & 0.821 & 0.829 & 0.976 \\
20 & 0.813 & 0.784 & 0.976 \\
21 & 0.715 & 0.715 & 0.977 \\
22 & 0.775 & 0.780 & 0.977 \\
23 & 0.768 & 0.758 & 0.977 \\
24 & 0.789 & 0.781 & 0.977 \\
25 & 0.790 & 0.739 & 0.977 \\
\hline
\end{tabular}

As can be seen, the correlations are high and the elimination of any of the items would not result in Cronbach's Alpha exceeding the value of 0.978 .

\subsection{Construct Validity}

To examine the construct validity of the designed instrument in its factor structure, a two-class factor analysis was performed, exploratory and confirmatory. With regard to the exploratory factor analysis, the division made into three dimensions of the scale of perceptions about the potential of film as a teaching resource in Pre-School and Primary Education corresponds, with a saturation index of 0.40 , to the three-factor structure. It is worth indicating that the variables were established as categorical. In this sense, if we consider the distribution of the items according to the factors, factor 1, cinema as a didactic resource of content transmission, includes items 1 to 9 , and factor 2 , cinema as a didactic resource of expression and communication, is integrated by items 10 to 17. On the other hand, factor 3 , cinema as a didactic resource of critical analysis, is composed of items 18 to 25 .

In relation to the analysis of explained variance, the results show that factor 1 explains $62.459 \%$, factor 2 explains $9.238 \%$ and factor 3 explains $5.044 \%$, with the total variance explained by the three factors being $76.741 \%$. The analysis has also shown a high Cronbach's Alpha in the three factors, specifically, 0.958 in the first two factors and 0.955 in the third factor.

As regards the confirmatory factor analysis, the results obtained confirm a three-factor structure, as can be seen in Figure 1.

As can be seen, the weights or factor loads of the items are high, being higher than 0.80 . In this sense, it should be noted that the items that best define the factor 1 are items 5 and 8 with 0.905 and 0.935 , respectively. On the other hand, the two items that have more weight in the factor 2 are 15 and 16, both with 0.938. Finally, items 19 and 20 were the ones that have more weight in factor 3 .

As for the goodness-of-fit indexes of the three factors, the results show a comparative fit index (CFI) of 0.957 , a root mean square (RMSEA) of 0.109 and a standardized root mean square (SRMR) of 0.032. It should be noted that, according to [53], the values for considering a model to have a good fit are a CFI equal to or greater than 0.95, an RMSEA not greater than 0.10 and an SRMR less than 0.05. The values obtained reflect that the CFI index has a high comparative fit value above 0.95 and the error rate reflecting the SRMR is low, below 0.05. Additionally, the RMSEA index is within the observed limit of 0.10 .

Finally, the Cronbach's Alpha of the three factors in the confirmatory analysis is high, 0.965 at factor $1,0.963$ at factor 2 and 0.961 at factor 3 . 


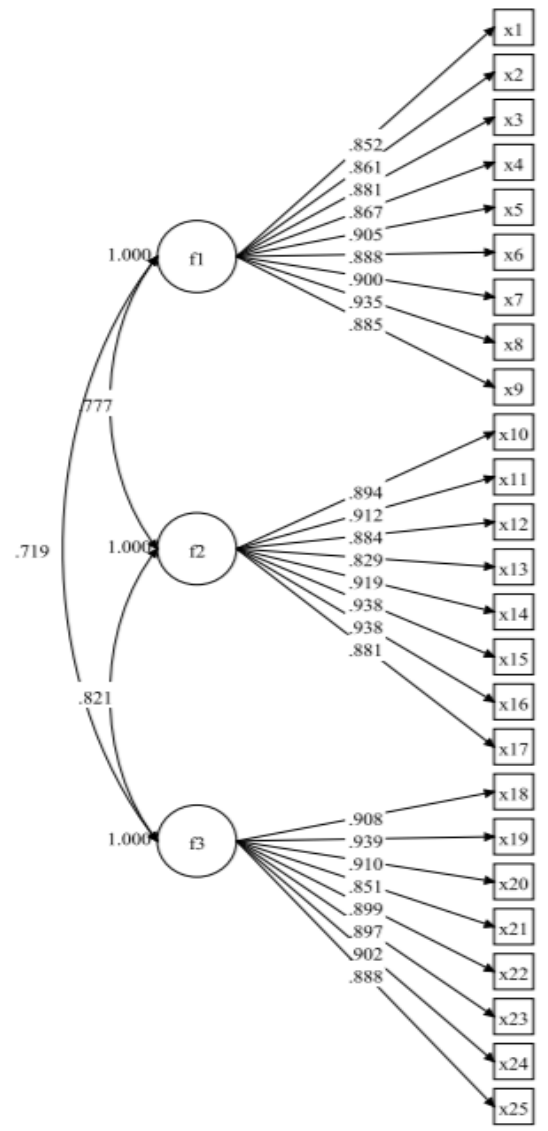

Figure 1. Factor distribution diagram in confirmatory factor analysis.

\subsection{PECID Questionnaire}

After addressing the content validity, reliability and construct validity of the PECID questionnaire, the following table (Table 5) presents the statements of the 25 items that make up the scale of perceptions of the Teacher's Degree students on the potential of cinema as a teaching resource according to its three dimensions or factors.

Table 5. Items of the scale on the Teacher's Degree students' perceptions about the potential of cinema as a didactic resource in Pre-School and Primary Education.

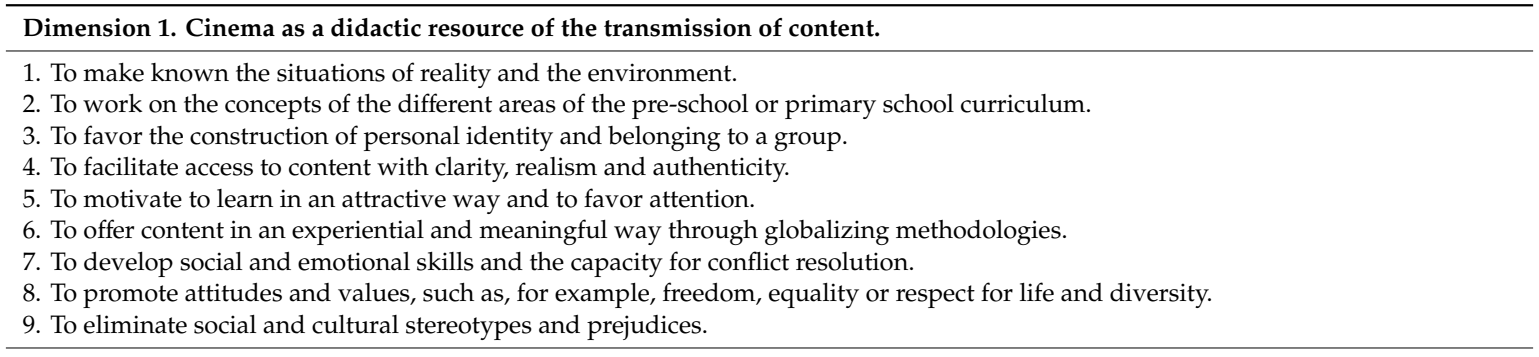

10. To develop imagination and creativity.

11. To increase the artistic audio-visual, plastic and musical senses.

12. To implement imitation and dramatization activities in a practical way, such as, for example, roleplaying, symbolic game or rule game.

13. To handle technological tools (cameras, sound recorders, editing programs, etc.) to perform audio-visual tasks.

14. To acquire the competence to express themselves and communicate through images and sounds, building audio-visual proposals individually.

15. To develop the expression and communication strategies in a cooperative way with the realization of audio-visual work projects.

16. To develop expressive and communicative skills and abilities at oral and gesture level.

17. To develop expressive and communicative skills and abilities at a written level (for example, with the writing of a script or a story). 
Table 5. Cont.

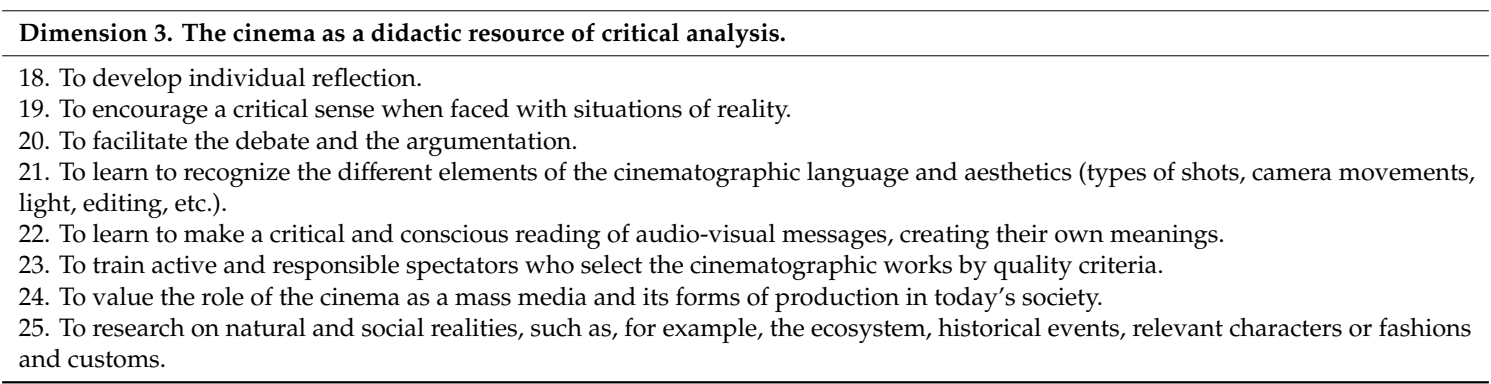

\section{Discussion}

The aim of this work was to design and validate an instrument to measure the perceptions of future teachers in Spain about the potential of film as a teaching resource in pre-school and primary education. To do so, a systematic and planned process was followed, which resulted in the PECID questionnaire, a valid and reliable instrument that allows quantifying in its different dimensions how the students of the Teacher's Degree perceive cinema as a resource for their future teaching practice. Some instruments have been designed and validated for educational resources such as ICTs [54-58], but the PECID questionnaire is the first to address the perception of cinema in education. This fact shows the novelty of the instrument obtained.

If we consider the results regarding content validity, it was found, after the expert judgment, that three items were irrelevant based on the quantification carried out by applying the CVC by [49]. The elimination of these items implied obtaining an instrument with 25 items with good content validity. This allowed us to affirm, taking into account what [59] said about content validity, that the sample of items collected in the PECID questionnaire effectively measure the specific domain it intends to measure and no other. Likewise, with the pilot test carried out, improvements could be implemented based on direct contact with a reduced sample of students, serving as a complement to the opinions issued by the experts. On the other hand, if we consider the reliability, the findings obtained showed an excellent internal consistency of the instrument. In this sense, Cronbach's Alpha coefficient allowed us to determine the extent to which the different items were related to each other, and a high relationship was found between them. Likewise, accuracy in the measurement was guaranteed, since based on what [60] said, it can be stated that the repeated application of the PECID questionnaire to the same subject or object will largely produce the same results.

Regarding construct validity, the factor analyses conducted (exploratory and confirmatory) reflected that the constitutive definition made of the construct, decomposed into three factors or dimensions, is adequate. In this sense, it was found that the educational potential of cinema can be structured around cinema as a resource for the transmission of content, cinema as a resource for expression and communication, and cinema as a resource for critical analysis. In the first factor, the most defining potential was to foster attitudes and values (item 8), while in the second factor, the most important was to develop expression and communication strategies in a cooperative manner with the realization of audio-visual work projects, together with the development of expressive and communicative skills and abilities at the oral and gestural level (items 15 and 16). In the third factor, the potential that most defines cinema as a resource for critical analysis is to encourage a critical sense in the face of real-life situations (item 19).

\section{Conclusions}

Based on the results obtained and bearing in mind the objectives set, the following conclusions were indicated:

1. The instrument designed has a valid content;

2. The instrument has a reliable internal consistency; 
3. The instrument has a valid factorial structure, in accordance with the construct it measures.

As a limitation of the study, it is worth mentioning the fact that five Spanish private universities refused to collaborate in the study. This means that a larger and more balanced sample could not be obtained, and that not all students from all universities did participate.

The PECID questionnaire is ready to be applied in a concrete way in the groups of students of the Teacher's Degree that are considered for the diagnosis of their perceptions about cinema in education. By collecting data concerning the didactic possibilities of cinema in a complete and structured way, it should serve for the knowledge and reflection of the students. In this way, it tries to make visible the diverse didactic possibilities detected and to be a stimulus to deepen in the direct application of cinema, which supposes an advance in its implantation. In order to contribute to a future application of cinema in education, it is appropriate to generate a positive perception of it through knowledge. In this line, institutional policies should be adopted to guarantee the presence of cinema in classrooms through the provision of resources. In addition, activities should be conducted in the faculties of education that seek to disseminate and value a cinema of a special cultural and educational nature. On the other hand, measures should be taken to implement specific training for the optimal use of cinema in education. In this sense, a specific subject could be included that deals with the training of audio-visual resources, such as cinema, for its educational use. Cinema could also be considered as a resource to work transversally in the curriculum. The instrument designed and validated can be taken as a reference framework for developing training in its three dimensions for future teachers.

The research conducted is a pioneer in the field and aims to be complemented by future studies from other approaches. In this line, it could be deepened in the measurement of the perceptions of other educational groups, such as, for example, the teachers in exercise in Pre-School and Primary Education. On the other hand, it is important to continue advancing in the research that explores the possibilities of cinema for the improvement of education in favor of an active and technological learning.

Funding: This research received no external funding.

Acknowledgments: The author would like to thank the teachers who participated in the expert judgement and the teachers from the Spanish universities who collaborated in the dissemination of the PECID questionnaire. The author would also like to thank Juan Luis Castejón Costa and Alejandro Veas Iniesta for their advice.

Conflicts of Interest: The author declares no conflict of interest.

\section{References}

1. Herrero, C.; Sanchez-Requena, A.; Escobar, M. Una propuesta triple: Análisis fílmico, traducción audiovisual y enseñanza de lenguas extranjeras. inTRAlinea Online Transl. J. 2017, 19, 1-10.

2. Amar, V. Comprender y Disfrutar el Cine. La Gran Pantalla Como Recurso Educativo; Grupo Comunicar Ediciones: Huelva, Spain, 2003.

3. Lara, F.; Ruiz, M.; Tarín, M. Cine y Educación; Academia de las Artes y las Ciencias Cinematográficas de España: Madrid, Spain, 2019.

4. Sánchez, W.; Uribe, A.; Restrepo, J. El cine: Una alternativa de aprendizaje. Trilogía Cienc. Tecnol. Soc. 2019, 11,39-62. [CrossRef]

5. Smithikrai, C. Effectiveness of Teaching with Movies to Promote Positive Characteristics and Behaviors. Procedia-Soc. Behav. Sci. 2016, 217, 522-530. [CrossRef]

6. Gutiérrez-Bueno, B.; Molina-García, M.J. El cine como herramienta para trabajar la diversidad cultural: Investigación en aulas interculturales. Modul. Rev. Cient. Sobre Divers. Cult. 2019, 3, 78-93. [CrossRef]

7. De Leeuw, R.; Van der Laan, C. Helping behavior in Disney animated movies and children's helping behavior in the Netherlands. J. Child. Media 2018, 12, 159-174. [CrossRef]

8. Kubrak, T. Impact of Films: Changes in Young People's Attitudes after Watching a Movie. Behav. Sci. 2020, 10, 86. [CrossRef]

9. Orefice, C. Guidelines for an "Operative Constructivism" in the Learning Process through Cinema. The Film Archive for Medical Education of the University of Florence. Rev. Med. Cine 2014, 10, 127-132. 
10. Sevillano, M.; De la Torre, S.; Carreras, C. El cine, recurso formativo. 18 años de investigación del grupo GIAD. Pixel-Bit Rev. Medios Educ. 2015, 46, 87-101.

11. Mak, A.; Hutton, J. Using feature films to teach Public Relations: An assessment model from non-major students' perspective. J. Mass Commun. Educ. 2014, 69, 386-403. [CrossRef]

12. Núñez-Gómez, P.; Cutillas-Navarro, M.; Álvarez-Flores, E. Cine como herramienta de aprendizaje creativo en Educación Primaria. Estu. Sobre Educ. 2020, 38, 233-251. [CrossRef]

13. Martínez-Salanova, E. El valor del cine para aprender y enseñar. Comun. Rev. Cient. Comun. Educ. 2003, 20, 45-52.

14. Kanellopoulou, C.; Kermanidis, K.L.; Giannakoulopoulos, A. The Dual-Coding and Multimedia Learning Theories: Film Subtitles as a Vocabulary Teaching Tool. Educ. Sci. 2019, 9, 210. [CrossRef]

15. Marín, V.; González, I.; Cabero, J. Posibilidades didácticas del cine en la etapa primaria. La edad de hielo entra en las aulas. Edutec Rev. Electrón. Tecnol. Educ. 2009, 30, a123. [CrossRef]

16. González, M.; Martínez, E.; Pereira, C. Cine de animación y educación. Modelos de películas de animación y sus virtualidades educativas. RELAdEI Rev. Latinoam. Educ. Infant. 2018, 7, 99-126.

17. Blasco, P.; Moreto, G.; Pessini, L. Using movie clips to promote reflective practice: A creative approach for teaching ethics. Asian Bioeth. Rev. 2018, 10, 75-85. [CrossRef]

18. Lee, S.C. Integrating entertainment and critical pedagogy for multicultural pre-service teachers: Film watching during the lecture hours of higher education. Intercult. Educ. 2019, 30, 107-125. [CrossRef]

19. Urpí, C.; Vicente, J. La formación en la cultura audiovisual. Un taller de cine como propuesta pedagógica. Estud. Sobre Educ. 2008, 14, 85-104.

20. Checa-Romero, M. Developing skills in digital contexts: Video games and films as learning tools at primary school. Games Cult. 2016, 11, 463-488. [CrossRef]

21. Moura, A.; Cachadinha, M.; Almeida, C. Cinema Integrated Learning in Higher Education-the Case of Viana do Castelo Polytechnic-Northern Portugal. J. Educ. Soc. Policy 2017, 4, 143-151.

22. González, M. Cine y literatura para el aprendizaje de las competencias básicas: Vínculos semióticos y educativos. Educ. Siglo XXI 2015, 33, 175-194. [CrossRef]

23. Mateo, A.; Valera, P. Developing Multiple Intelligences Using Films in Primary Education. J. Educ. Pract. 2020, 3, 9-18.

24. Sales, N. Brazilian and Spanish Literature and Cinema: A Comparative Perspective. Publ. Fac. Educ. Humanid. Campus Melilla 2018, 48, 347-358.

25. Ley Orgánica 8/2013, de 9 de Diciembre, Para la Mejora de la Calidad Educativa (LOMCE). Available online: https://www.boe.es/buscar/pdf/2013/BOE-A-2013-12886-consolidado.pdf (accessed on 2 September 2020).

26. Real Decreto 1630/2006, de 29 de Diciembre, por el que se Establecen las Enseñanzas Mínimas del Segundo ciclo de Educación Infantil. Available online: https://www.boe.es/buscar/pdf/2007/BOE-A-2007-185-consolidado. pdf (accessed on 2 September 2020).

27. Real Decreto 126/2014, de 28 de Febrero, por el que se Establece el Currículo Básico de la Educación Primaria. Available online: https:/www.boe.es/buscar/pdf/2014/BOE-A-2014-2222-consolidado.pdf (accessed on 2 September 2020).

28. Domingo-Coscolla, M.; Bosco, A.; Carrasco, S.; Sánchez, J.A. Fomentando la competencia digital docente en la universidad: Percepción de estudiantes y docentes. Rev. Investig. Educ. 2020, 38, 167-782.

29. Prats, E. La formación inicial docente entre profesionalismo y vías alternativas: Miradas alternativas. Bordón Rev. Pedagog. 2016, 68, 19-33. [CrossRef]

30. Jiménez-Tenorio, N.; Aragón Núñez, L.; Oliva Martínez, J.M. Percepciones de estudiantes para maestros de educación primaria sobre los modelos analógicos como recurso didáctico. Ensen. Cienc. 2016, 34, 91-112.

31. Muñiz, J.; Fonseca-Pedrero, E. Construcción de instrumentos de medida para la evaluación universitaria. Rev. Investig. Educ. 2008, 5, 13-25.

32. Bisquerra, R. Metodología de la Investigación Educativa; La Muralla: Madrid, Spain, 2004.

33. Lorenzo-Lledó, A.; Lledó, A.; Pérez-Vázquez, E.; Lorenzo, G. Cinematographic Habits of Future Spanish Teachers from a Socio-Educational Perspective. Int. J. Environ. Res. Public Health 2020, 17, 5361. [CrossRef]

34. Smith, S.T. On construct validity: Issues of method measurement. Psychol. Assess. 2005, 17, 396-408. [CrossRef]

35. Cardona, M.C. Introducción a los Métodos de Investigación en Educación; EOS: Madrid, Spain, 2002.

36. Munthén, L.K.; Munthén, B.O. Mplus User's Guide, 8th ed.; Munthén \& Munthén: Los Ángeles, CA, USA, 1998-2017. 
37. Hair, J.F.; Anderson, R.E.; Tatham, R.L.; Black, W.C. Multivariate Data Analysis; Prentice Hall: New York, NY, USA, 1998.

38. Curran, P.J.; West, S.G.; Finch, J.F. The robustness of test statistics to nonnormality and specification error in confirmatory factor analysis. Psychol. Methods 1996, 1, 16-29. [CrossRef]

39. Schuman, H.; Presser, S. Questions and Answers in Attitude Surveys; Academic Press: San Diego, CA, USA, 1981.

40. Garland, R. The midpoint on a rating scale: Is it desirable? Mark. Bull. 1991, 2, 66-70.

41. Johns, R. One size doesn't fit all: Selecting response scales for attitude items. J. Elect. Public Opin. Parties 2005, 15, 237-264. [CrossRef]

42. Velez, P.; Ashworth, S.D. The impact of item readability on the endorsment of the midpoint reponse in surveys. Surv. Res. Methods 2007, 1, 69-74.

43. Baka, A.; Figgou, L. 'Neither agree, nor disagree': A critical analysis of the middle answer category in voting advice applications. Int. J. Electron. Gov. 2012, 5, 244-263. [CrossRef]

44. Almanasreh, E.; Moles, R.; Chen, T.F. Evaluation of methods used for estimating content validity. Res. Soc. Adm. Pharm. 2019, 15, 214-221. [CrossRef] [PubMed]

45. Escobar-Pérez, J.; Cuervo-Martínez, A. Validez de contenido y juicio de expertos: Una aproximación a su utilización. Av. Med. 2008, 6, 27-36.

46. Barroso, J.; Cabero, J. La utilización del juicio de experto para la evaluación de TIC: El coeficiente de competencia experta. Bordón Rev. Pedagog. 2013, 65, 25-38.

47. Hyrkäs, K.; Appelqvist-Schmidlechner, K.; Oksa, L. Validating an instrument for clinical supervision using an expert panel. Int. J. Nurs. Stud. 2003, 40, 619-625. [CrossRef]

48. Pedrosa, I.; Suárez-Álvarez, J.; García-Cueto, E. Evidencias sobre la Validez de Contenido: Avances Teóricos y Métodos para su Estimación. Acción Psicol. 2013, 10, 3-18. [CrossRef]

49. Hernández-Nieto, R.A. Contributions to Statistical Analysis; Universidad de Los Andes: Mérida, Venezuela, 2002.

50. Soriano, A. Diseño y validación de instrumentos de medición. Diá-Logos 2015, 14, 19-40.

51. McMillan, J.H.; Schumacher, S. Research in Education, 6th ed.; Pearson Educación: Boston, MA, USA, 2006.

52. George, D.; Mallery, P. SPSS for Windows Step by Step: A Simple Guide and Reference. 11.0 Update, 4th ed.; Allyn \& Bacon: Boston, MA, USA, 2003.

53. Hu, L.T.; Bentler, P.M. Cutoff Criteria for Fit Indexes in Covariance Structure Analysis: Conventional Criteria versus New Alternatives. Struct. Equ. Model. Multidiscip. J. 1999, 6, 1-55. [CrossRef]

54. Lima, A.; Da Silva, G.; Bousquet-Santos, K. Validation of a Questionnaire on ICTs (Information and Communication Technologies) Skills of Undergraduate Health Students in Brazil. Psychol. Res. 2013, 3, 1-6.

55. Mirete, A.B.; García-Sánchez, F.; Hernández, F. Cuestionario para el estudio de la actitud, el conocimiento y el uso de TIC (ACUTIC) en Educación Superior. Estudio de fiabilidad y validez. Rev. Interuniv. Form. Profr. 2015, 83, 75-89.

56. Jiménez, V.; Alvarado, J.M.; Llopis, C. Validación de un cuestionario diseñado para medir frecuencia y amplitud de uso de las TIC. Edutec Rev. Electron. Tecnol. Educ. 2017, 61, a368.

57. George, C.; Trujillo, L. Aplicación del Método Delphi Modificado para la Validación de un Cuestionario de Incorporación de las TIC en la Práctica Docente. Rev. Iberoam. Eval. Educ. 2018, 11, 113-134. [CrossRef]

58. Domínguez, R.; Hérnandez, A.; Chica, E. Development and validation of a questionnaire for evaluating the impact of ICT in secondary schools. Digit. Educ. Rev. 2018, 34, 1-26.

59. Corral, Y. Validez y confiabilidad de los instrumentos para la recolección de datos. Rev. Educ. Cienc. 2009, 19, 228-247.

60. Gento, S. Guía Práctica para la Investigación en Educación; Sanz y Torres: Madrid, Spain, 2004.

(C) 2020 by the author. Licensee MDPI, Basel, Switzerland. This article is an open access article distributed under the terms and conditions of the Creative Commons Attribution (CC BY) license (http://creativecommons.org/licenses/by/4.0/). 